\title{
Meaning Making in Growing Up Without a Father: Narratives of Young Adolescent Boys
}

\author{
Malose Langa* \\ School of Community and Development, University of Witwatersrand, Private Bag x3, 2050, Johannesburg, South \\ Africa
}

\begin{abstract}
This article explores young adolescent boys' narratives and lived experiences of growing up without fathers. We conducted Individual interviews with thirty-two adolescent boys, and used discursive data analysis methods to analyse meanings that these participants made about growing up without fathers. We found that participants in the study embraced alternative voices of masculinity that were not destructive to the self and others, despite growing up without father figures. This contradicts the mainstream literature which holds that boys who grow up without fathers are highly likely to experience emotional disturbances and indulge in risk-taking behaviours.
\end{abstract}

Keywords: Absent father, adolescent boys, Alexandra, fatherhood, hegemonic masculinity, risk-taking.

\section{INTRODUCTION}

For the purpose of this article absent fathers or father figures refer only to biological fathers who are absent through death, absent with occasional contact, absent with regular contact or absent with no contact at all $[1,2]$. It is acknowledged that the definition of a father cannot only be limited to biological fathers, since individuals such as uncles, brothers, grandfathers, male teachers and other male figures can also play a significant role as father figures to children who grow up without biological fathers [3, 4]. The focus of the current article explores experiences of adolescent boys who grew up without biological fathers.

Many studies $[1,5,6]$ indicate that a child, especially a boy, needs his father's love and care. These studies argued that the father's presence enhances children's emotional well-being, whereas the absence of the father is often associated with emotional disturbances, including aggression and violent behaviours as well as poor social competence and academic problems [7,8]. The dominant view in the existing literature is that boy children growing up without their fathers are more likely to experience emotional and behavioural difficulties transitioning into adulthood. The current article aims to explore and investigate this view.

It is important to note an emerging literature concerning young adolescent boys who grew up without father figures but who, despite this lack, embraced alternative aspects of adolescent masculinities that were non-risking, non-violent and non-sexist [2, 3, 9]. Findings of these studies by [3] and [2] raise questions about the 'idealisation' of fatherhood as a panacea to all social ills associated with young adolescent boys who grow up without father figures. Although the

*Address correspondence to this author at the School of Community and Development, University of Witwatersrand, Private Bag x3, 2050, Johannesburg, South Africa; Tel: 0735049890;

E-mail: malose.langa@wits.ac.za father-son relationship is important, it cannot be simplistically assumed that the absence of father figures will necessarily result in maladjustment in the lives of all adolescent boys. In fact, in some families, some fathers play destructive roles in raising their boy children, as these fathers are not positive role models $[10,11]$. Some studies found single mothers played a positive role in raising boy children, despite lack of father figures [12].

We conducted interviews with adolescent boys to explore meanings made out of their lived experiences of growingup without fathers in their personal lives. How did the experience of growing up without fathers affect this group of adolescent boys? Did this experience affect them in terms of their personal lives and the aspirations they developed about the future as well as fantasies of future fatherhood later in life? Did this experience also push them to embrace violent or non-violent voices of masculinity?

\section{METHOD}

\section{Research Design}

This study used a qualitative approach, which is defined by [13] as an interpretative and critical approach to the process of data collection and analysis. Qualitative research methods were suitable for this study to help the researcher to understand adolescent boys' emotional talk about growing up without fathers and their perceptions of the impact of this on their personal lives and future aspirations of being fathers themselves.

\section{Research Setting}

We recruited a group of thirty two adolescent boys from two secondary schools in Alexandra Township, South Africa, which is a historically black township situated on the northern side of Johannesburg. Alexandra, like many other South African townships, has a high rate of social problems, such as poverty, unemployment, overcrowding, crime, pollution, poor electricity supply, and a lack of clean water. 
We chose the township of Alexandra (popularly known as Alex) as a research site to explore how township adolescent boys talk about the impact of absent father figures in their lives and how growing up under all these difficult circumstances, shaped their personalities and involvement in risk-taking behaviours.

\section{Participants}

The thirty-two adolescent boys were aged between 14 to 18 years in grade 10 to 12 at the time when they were recruited for the interviews. The researcher made follow-ups with some boys (sixteen of them) over a period of 8 years. Over this period, some participants completed matric, and some went to various institutions of higher learning while others opted to find jobs due to financial difficulties to pursue their studies. Some of the participants in the process of being followed, dropped out of school, while others became young fathers. This introduced an interesting dimension to the research about how lack of father figures in their personal lives motivated them to want to be different as compared to their absent father figures.

We considered key ethical considerations when giving the participants the information sheets explaining the nature of the study. All the participants who expressed an interest to participate were given consent forms for their parents/guardians' permission before they participated in the study. We mentioned that participation in the study was voluntary and that we use pseudonyms in any written material to protect participants' identities.

\section{Data Collection Methods}

Individual interviews arranged with each boy after three focus groups to discuss what it meant to be a boy growing up in the township of Alexandra. Individual interviews were very useful in allowing the participants to talk about their disappointment with absent fathers, feelings of rejection, and they also expressed aspirations about future fatherhood.

The researcher read all the transcripts and had follow-up individual interviews with sixteen boys whose material was particularly interesting in terms of growing up without fathers. In the study about adolescent masculinity conducted by [14] they used the method of follow-up interviews to good effect. The researcher found the follow-up individual interviews very useful in clarifying issues, and supplementing narratives which emerged in both individual interviews and focus groups. The participants also reported that they found the follow-up individual interviews helpful in reflecting at a deeper level on the meaning of being adolescent boys (they were young men at the time of followup interviews) in their township context, growing up without fathers.

\section{Data Analysis}

Based on the work of [15] and [16] we audio-recorded and transcribed all interviews for detailed discursive analysis. Discursive analysis suited the analysis of meanings that the participants made about their absent fathers. In the data analysis, we paid particular attention to the feelings and emotions that the participants shared about growing up without fathers.

\section{FINDINGS AND DISCUSSION}

Out of thirty participants, nineteen adolescent boys mentioned that they did not know their fathers, six knew their fathers but were not living with them and their fathers had separated from their mothers. The mainstream literature on fatherhood indicates that boys growing up without father figures are more likely to experience emotional disturbances, including displaying aggression, violent behaviour and vulnerability to drug abuse. Some boys in this study constructed positive male identities, despite the lack of father figures in their lives. These findings challenge the simplistic assumption that the absence of fathers will necessarily result in maladjustment. A range of internal and external factors can help adolescent boys develop a positive masculine identity, despite such circumstances.

\section{Searching for the Absent Biological Fathers}

Many participants not knowing their fathers spoke about the wish to meet them. They were all emotional (e.g. crying in the interview) when they spoke about lack of biological father figures in their personal lives and some were eager to go out and search for their absent father figures. For example, following our first individual interview, one participant $\left(\right.$ Benny $\left.{ }^{1}\right)$ went home to ask his mother about his absent father who he had never met. In the follow-up individual interview (three months after), Benny said that the first interview evoked feelings in him such as: "I want to know who I am. I want to know who my father is". He spoke with his mother who told him that his father left during her pregnancy and she lost contact with him but that she heard that he was living somewhere in Ga-Marule (a remote rural area in Limpopo Province). At the time of the follow-up interview, Benny was still making plans to trace his father based on this information. In particular, he wanted to know what his father looked like. "Does he look like me?" he asked rhetorically in the interview. Similar to [17] findings, Benny also stated that he wants to change his surname to his father's surname because he saw this as important for his acceptance by his father's ancestors and for adopting Pedi cultural practices to align with his father's line of heritage. Interestingly, Benny attributed some of his behavioral problems, such as smoking, drinking and poor academic performance, to a lack of connection with his father's ancestors. He believed he could solve his problems by meeting his father and performing certain rituals to cleanse himself so that he could behave like a 'real' man. In this interview, we observed with interest how Benny explained his risk-taking behaviors as an adolescent boy by drawing on a cultural discourse. In his anthropological work [18], found that in some cultures they regarded fathers as important male figures who helped their sons and other boys in the community develop certain attributes of masculinity. Rituals, such as the attendance of initiation school, played a key role in assisting adolescent boys to identify with their fathers and other male figures as role models. According to [3] identification with fathers and other male figures in the community is a crucial marker of being a 'real' boy.

Psychoanalytic literature regards identification with a father as an important aspect of masculine gender identity development [19]. In our study, Benny also wanted to

\footnotetext{
${ }^{1}$ Pseudonyms are used to protect the identity of the participants in the study.
} 
identify with his father by taking his surname, recognizing that this holds some symbolic meaning. Connecting with his ancestral spirits by taking his father's surname is an important culturally supported step in developing a positive masculine gender identity. It frustrated Benny that he never met his father and also fantasized that his father would help him to better understand the meaning of being an adolescent boy and becoming a man by giving him guidance and support.

In the bulk of the interviews, adolescent boys who grew up without biological fathers presented an image of the 'ideal' father as someone who cared about and loved his children and spent time talking to them about self-protective behaviors. This is illustrated in the quotes below:

William: "I started doing bad things at an early stage like smoking, drinking and going to parties. And I know if my father was here, I wouldn't have done that. So I got freedom at an early age. And as you can understand in the township life is fast, things happen."

Nathan: "Yeah, I believe that if my father he would have spent time with me teaching me about life and so forth because he was also young like me."

Absent fathers were often attributed potentially positive and helpful qualities, even when there was some evidence that some fathers played a destructive role in their boy children's lives [10]. It is questioned whether this sometimes compensatory idealization, assisted the boys in the study in dealing with feelings of lack and loss. Some of the participants also shared their fantasies of how their lives would be different if their absent fathers were present, for example by buying them clothes and guiding them as young boys about the meaning of being a male person. It was clear in the interviews that the boys believed the absent fathers would provide direction or guidance and take away their feelings of sadness, frustration, confusion, conflict and depression if they were present. However, many of the participants also realized that their wishes to meet their absent fathers were unrealistic and that their father-related fantasies might be just a pipe dream.

Simon: "I just need to accept the situation. My mother has been encouraging to forget my father."

Nathan: "I must just forget about him because since, since nothing. No phone call... and nothing."

Convincing themselves to give up on the hopes of their absent fathers was not an easy process because of the recurring fantasies they recounted. For example, in Simon's words:

"Like I used to ask my mother, is he a nice guy? And my mother used to say negative things about him. And then at times I used to say maybe she is saying this because he does not live with me and all that. But I think I am starting to believe those things that he was not such a great guy."
His father left when he was three weeks old (according to his mother) and Simon worked hard to find some way of redeeming him in his mind, as a young man, he began believing his mother that his father is not such a 'good person'. Initially, he thought his mother spoke negatively about his father because he abandoned her and that she was therefore, biased in her assessment, but he is now more willing to give up his own fantasy to meet with him and to appreciate the truth of his mother's assessment. Boys like Simon, Nathan and others developed some healthy ways of coping with absent father figures in their personal lives by investing in future academic career goals as discussed in the subsequent section.

\section{INVESTING IN THE FUTURE}

Many of the participants in the study rejected and subverted the automatic association of masculinity with violence as normative amongst adolescent boys living in predominantly black townships, such as Alex. The interviews showed the importance of academic success as a factor in resisting involvement in risk-taking behaviors such as substance abuse, and participation in crime as well as violence:

Alfred: "It is not easy growing without your father but now I don't care about being popular or what. I only care about my future. My future comes first.",

Herman: "I care only more about my school work. Yeah, myself I don't care about being violent or showing other boys that I'm strong and I can fight with other boys. I just have to work hard for my own future as there is no father to support me."

Martin: "I don't want to be making excuses because I grow up without a father...... but I don't think fighting with other boys makes you a 'real' boy. That is for boys that are stupid."

Despite growing up without fathers, these boys clearly embraced masculine voices that were non-violent, non-risk taking, and school orientated. The study proved academic success as the main protective factor in mitigating against participation in risk-taking behaviors. This is similar to [11]'s findings in Brazil that young adolescent males who perform well academically are less likely involved in risktaking behaviors such as gang violence. They were not concerned how they appeared to others, but how they performed academically in preparation for the future. These participants also expressed significantly higher levels of optimism and confidence about the future than their peers who were involved in criminal activities. For example, one of the boys, Themba, a 16 year-old boy, who grew up without a father spoke painfully in the interview about how his peers, who were involved criminal activities, teased him by calling him a bookworm because he always studied while they loitered on the streets. He asserted that he consoled himselfby thinking, "let's put five years down the line and see what is going to happen; who is going to be a bookworm, who is going to wash whose car, who is going to be whose garden boy, who is going to ... you know stuff like that because I will be working and having my own family and children". Themba seemed to be coping well and resisted 
peer pressure to engage in criminal activities. He narrated that he saw education as an investment for the future. He believed that although he currently occupied an inferior position later he would be in a superior position once he had completed his university degree that some of the boys who were currently teasing him would be washing his car or working as garden boys in his big house.

In fact, this group of adolescent boys saw pursuing academic work as an investment in the future and also as a possible means to break the cycle of poverty in their lives in Alexandra Township. Interestingly, all the participants also spoke about wanting to be 'different' fathers as compared to their absent fathers; the discussion follows below.

\section{BECOMING DIFFERENT FATHERS THEMSELVES}

Many participants spoke about their fantasies to be different fathers as compared to their absent fathers. However, it was difficult to predict whether they would able to achieve all their fantasies but three participants became teenage fathers during the follow-up interviews conducted over a period of two to eight years. This provided the researcher with some opportunity to ask whether or not they fulfilled all the dreams of fatherhood shared before they became fathers.

\section{PAYING INHLAWULO (DAMAGE MONEY FOR IMPREGNATING A GIRL OUT OF WEDLOCK) OR NOT MY CHILD IS MY CHILD}

All the three young teenage fathers in the study asserted that it took them three to four months before they told their parents about their girlfriends' pregnancy. Nelson (one of the teenage fathers in the study) argued that he did not immediately tell his parents because culturally, he expected his girlfriend's family to come to his house and report that he had impregnated their daughter [18] confirms that in terms of cultural rules, the girl's family has to go to the boy's family to report the matter once they discover that their daughter is pregnant. In Pedi culture, this custom is known as 'go latlapatla gore ngwanawalena o robilengwanawarenaleoto' (meaning "we are here to report that your son has impregnated our daughter"). In return, the boy's family has to pay 'isisu or inhlawulo' (damage money for impregnating a girl out of wedlock) if their son accepts paternity $[2,18,20]$. In the past, paying damages involved handing over livestock, but today in modern society paying damages involves the payment of money. In their studies, [18] and [2] found that paying 'isisu' was at times an impediment to fatherhood because many boys and young men refused to acknowledge paternity and deserted their children owing to their inability to afford this 'damage' payment. As a result, [2] concluded that 'inhlawulo' had largely lost its cultural significance as a symbol of apology to a girl's family because of the high cost of the damages in the modern society.

However, in the present study, the three teenage fathers did not deny their paternity. It was not clear whether they accepted this in part because their girlfriends' families did not approach their families to demand they pay 'inhlawulo' and therefore they did not negotiate the affordability of acknowledging paternity. In the extract below, Nelson, a 17- year-old teenage father, asserted that he would have acknowledged paternity in any case.

Nelson: "I would not deny paternity. They (his friends) were talking like that, but I would not deny my blood. I would never deny my child."

In the above extract, Nelson mentioned his peers advised him to deny paternity when he told them about his girlfriend's pregnancy. He vehemently rejected their advice saying he could not disown his own 'blood'. He argued that refusing to acknowledge one's own blood would bring bad luck and possibly anger the ancestors. After the birth of his child, 'mopasowa go begangwana' (a cultural ritual to introduce the child to the ancestors) took place. He believed that the birth of a child was a gift to be celebrated, even though it was an unplanned child. His newly born baby boy was central in his life. Unlike his absent father, he wanted to be there for his child and take good care of him.

Nelson: "Yeah, I did not listen to my friends when they said I must deny paternity of my child because I wanted to be there for my baby boy. I wanted him to have all the love I did not have from my father."

In the above extract, Nelson, in this new relationship with his baby son took his absent father's position, and his son took his position. By taking good care of his baby boy, he seemed to be vicariously fulfilling some of his unmet emotional needs as a boy child [19]. The interview revealed that the birth of his boy child also reactivated some of his unresolved childhood issues with regard to his absent father.

Nelson: "Yes. It is painful growing up, not knowing your father. I really want to be a different father."

Other teenage fathers interviewed in the study also shared Nelson's view about wanting to be a different father.

Thabo: "I don't want to be like my father who was absent. I'm there for my child. I don't my child to suffer like I did you see."

Oupa: "I just want my child to have the love of a father - something which I have not had. I'm there for my child."

The other two teenage fathers also spoke about wanting to be 'good' fathers, in contrast to own absent fathers, suggesting that in becoming fathers their own experiences of being fathered were evoked, probably both consciously and unconsciously. This confirms [21]'s view that men approach the birth of their children filled with all their fantasies and fears about their own childhood. Fatherhood is about repairing father-son relationships through resolving intrapsychic conflicts in this regard. Building on [22]'s work, this confirms [23] arguments that becoming a father evokes oedipal conflicts and early childhood memories. The narratives shared by Nelson, Thabo and Oupa illustrate how through the experience of being a new father, some men are able to resolve aspects of their oedipal issues with their own absent fathers, in that being a good father helps them fulfill their own unmet needs of having grown up without fathers in their lives. 


\section{BEING A FATHER WHO IS EMOTIONALLY PRESENT}

The three participants reported that they were actively involved in their children's lives, thus contradicting the dominant view in the literature that teenage fathers very seldom accept responsibility for supporting their children [24]. Studies by [20] and [9] confirm the findings of this study that some fathers are slowly becoming emotionally present for their children.

Oupa: "Sometimes she (the participant's child) gets sick and you find that I have stress because I was at the clinic the whole night and I can't go to school the following day. Those are the things that were stressing me. Sometimes I want to do something for her and then the next thing she's sick and I'm at the clinic and then I can't do my school work, I fall asleep in class and I get stressed."

Timothy: "I worry when he's sick or has a rash and think what if something happens to him."

Researcher: "When he's not feeling well do you become stressed?"

Timothy: "It happens sometimes when he's sick that his mother doesn't tell me and it's one of the things that stress me because she waits for me to ask her what's going on with the baby."

In their interviews, the participants also spoke about the emotional costs of being teenage fathers. For example, Oupa reported that the period immediately following his daughter's birth was highly stressful because he spent most of his time at the hospital with his daughter during her critical illness lasting nearly three months: "I had to be supportive to the mother (his girlfriend). I didn't want her to feel like she had the baby alone. We did this together...... I also help her change nappies and feed the baby". Here, Oupa, a 16-year-old teenage father, indicated that he was willing to take on the responsibility of supporting his girlfriend emotionally; he did not want her to feel alone in looking after their sickly child, whom he recognized as their joint responsibility. Oupa was also proud about taking on the conventionally female role of feeding his daughter and changing her nappies. He argued that as a teenage father he needed to do all these 'feminine' chores in order to bond with his daughter. He asserted that he has grown out of this experience of being a young father that he was more responsible and emotionally supportive to his girlfriend as well as their boy child.

Timothy, a 17-year-old teenage father, also believed he 'grew'as a result of his personal experience of becoming a young father. He reported that his character changed and that he is more responsible. He reported that after his baby boy was born, he stopped doing lot of things such as "having many girlfriends". For him, the meaning of his son's name Lesedi (Tswana word for light) was significant because he believed his son has become his 'light'. He was now able 'to see the light' and consequently avoided risk-taking behaviours such as drinking excessively or having sex with multiple partners. In the follow-up interview, he spoke about the importance of his loyalty and faithfulness to the mother of his child. His main goal was to complete his matric and to study for a Bachelor of Commerce degree at the University of Johannesburg.

The participants were also explicit about trying to offer their children a 'different' experience of growing up that was an improvement on their own father-related experiences:

Oupa: "I want to do things for my child so she can have a better life than I did and guide her not to experience the things that I did."

Nelson: "Yes, I really want to be a different father."

Researcher: "And do you think you would be free to talk to him [your son]?"

Nelson:" Yes. Because I do not want him to do the mistakes I did. I will also talk to him about sex and all that stuff."

The extracts above show that the participants were emotionally invested in being caring and non-damaging fathers. Being a 'good' teenage father was apparently about rectifying their absent fathers' mistakes as far as possible in their lived relationships with their newly born babies. For example, Nelson maintained that he would talk more openly to his son about issues of sex and teenage pregnancy to ensure that he did not make the same mistake of impregnating a girl at a young age. He believed he would not have made this mistake if he had a male figure in his life to guide him in this way. It was very clear that the teenage fathers did not want their newly born babies to experience the pain they had undergone. Oupa said that he would also be over-protective of his daughter and also open to talk to her about issues of sex later in life. Unlike his absent father, he was happy to spend time with his daughter:

\section{Oupa: "I'm staying with my mother here in Alex. Every weekend I go and fetch her. She stays at my place for the whole weekend. I play with her. You know yeah it's important for kids to be with their fathers."}

All the participants' views in this study signified that as teenage fathers they embraced voices of responsible fatherhood characterized by emotional care, love and concern. Despite their youthfulness, they adopted responsive and responsible roles in relation to their children and were willing to demonstrate values of 'new father' attributes. In this respect, the findings for the study regarding teenage paternity, although based on a very small population of three, suggest that boys are more willing to shoulder responsibility in this regard than is generally thought or expected, even if they grew up without biological father figures. The three participants who were young fathers seemingly developed a greater sense of purpose in life. It would be interesting to explore the long-term sustainability of these positive feelings about the self and plans for the future

\section{CONCLUDING REMARKS}

Despite growing up without biological fathers, the participants clearly embraced alternative notions of what it 
meant to be a boy, confirming an emerging literature that adolescent boys who grow up without fathers do not necessarily engage in violent or risk-taking behaviours $[2,3$, 20]. It is therefore important to create safe spaces to publicise and celebrate non-hegemonic norms of black township masculinity. In this study, it is evident that a focus on voices of resistance promotes the wider realisation that not all township boys are inherently violent, callous, and risk-takers, despite the lack of father figures in the participants' personal lives.

The study showed that some of the adolescent boys were strongly future orientated and that this was important in the willingness to sacrifice alignment with dominant or popular positions in the present and thus entertaining non-hegemonic or alternative identity positions. Their narratives revealed positive signs of change, ambition and the aspiration to achieve career goals. This group of adolescent boys saw the pursuit of academic work as an investment in the future.

It was also evident was that the lack of fathering experiences did not automatically lead to transgenerational transmission of poor or absent fathering. Despite the lack of a positive fathering experience, many of the participants revealed their desires to be 'good' fathers in comparison with their own absent biological fathers. The wish to be 'different' fathers evidently stemmed in part from their own lived experiences of lack, supporting the emerging literature [2] that some young men are slowly embracing alternative notions of masculinity despite growing up without father figures.

\section{CONFLICT OF INTEREST}

The author confirms that this article content has no conflict of interest.

\section{ACKNOWLEDGEMENTS}

The research project was funded by SANPAD (South African Netherlands Partnership on Alternative Development) and the National Research Foundation (NRF) and the African Doctoral Dissertation Research Fellowship (ADDRF) offered by African Population and Health Research Center (APHRC) in partnership with the International Development Research Centre (IDRC) and Ford Foundation. The author would like to thank all the participants in the study as well as research supervisor, Professor Gillian Eagle.

\section{REFERENCES}

[1] Padi T, Nduna M, Khunou G, Kholopane P. Defining absent, unknown and undisclosed fathers in South Africa. S Afr Rev Sociol 2014: 45 (2): 44-59.
[2] Swartz S, Bhana A. Teenage Tata: Voices of young fathers in South Africa. Cape Town: HSRC Press 2009.

[3] Langa M. Adolescent boys' talk about absent fathers. J Psychol in Africa 2010; 20(4): 519-529.

[4] Mkhize N. African traditions and the social, economic and moral dimensions of fatherhood. In: Richter L, Morrell R, Eds. Baba: Men and fatherhood in South Africa. Pretoria: HSRC 2006.

[5] Ramphele M. Steering by the stars: Being young in South Africa. Cape Town: Tafelberg Publishers 2002.

[ 6] Richter L, Morrell R. Baba: Men and fatherhood in South Africa. Pretoria: HSRC Press 2006

[7] Holborn L, Eddy G. So we are ATM fathers: A study of absent fathers in Johannesburg. Johannesburg: South African Institute of Race Relations 2011.

[8] Richter L. The importance of fathering for children. In; Richter L, Morrell R, Eds. Baba: Men and fatherhood in South Africa. Pretoria: HSRC 2006.

[9] Clowes L, Ratele K, Shefer T. Who needs a father? South African men reflect on being fathered. J Gender Stud 2013; 22(3): 255-67.

[10] Bozalek V. Representations of the family and South African families. In: De La Rey C, Duncan N, Shefer T, Van Niekerk N, eds. Contemporary issues in human development: A South African Focus. Cape Town: International Thomson Publishing 1997.

[11] Barker G. Dying to be men: Youth, masculinity and social exclusion. London: Routledge 2005.

[12] Manyatshe L. Why mothers won't tell: Narratives of factors that influence maternal non-disclosure of biological paternal identity [Unpublished dissertation] Johannesburg: University of the Witwatersrand 2013.

[13] Neuman LW. Social research methods: Qualitative and quantitative approaches. USA: Ally and Bacon 2000.

[14] Frosh S, Phoenix A, Pattman R. Young masculinities: Understanding boys in contemporary society. New York: Palgrave 2002.

[15] Potter J, Wetherell M. Discourse and social psychology: Beyond attitudes and behaviour. London: Sage 1989.

[16] Wetherell M, Edley N. Negotiating hegemonic masculinity. Femin Psychol 1999; 9(3): 335-56.

[17] Nduna M. Jewkes R. Undisclosed paternal identity in narratives of distress among young people in the Eastern Cape, South Africa. J Child Fam Stud 2011; 20(5): 303-21.

[18] Hunter M. Cultural politics and masculinities: Multiple-partners in historical perspective in Kwa-Zulu Natal. In: Reid G, Walker L, Eds. Men behaving differently. Cape Town: Double Storey 2005.

[19] Diamond MJ. The Shaping of masculinity: Revisioning boys turning away from their mothers to construct male gender identity. Int J Psychoanal 2005; 85(6 ): 359-80.

[20] Chili S. Perspectives and experiences of fatherhood among young people: a case study of 'black' students at University of KwaZuluNatal in Durban, KwaZulu-Natal. Masters Degrees (Population Studies), University of KwaZulu-Natal, Durban 2013.

[21] Diamond MJ. Becoming a father: A psychoanalytic perspective on the forgotten father. Psychoanal Rev 1986; 73(5): 445-68.

[22] Blos P. Son and father: Before and moving beyond the Oedipus complex. New York: Free Press 1985.

[23] Trowell J. Setting the scene. In: Trowell J, Etcheyogen A, eds. The importance of fathers: The Psychoanal Re-evaluation USA: Francis and Taylor 2002; pp. 3-19.

[24] Fagan J, Bernd E. Adolescent fathers' parenting stress, social support, and involvement with infants. J Res Adolescence 2007; 7(1): $1-22$. 